\title{
Call it Crass but There Is No Authority But Yourself: De-canonizing Punk's underbelly
}

Matt Grimes, Birmingham City University

\section{Abstract}

In popular music histories of punk, much has been documented on punk music and the formation of a punk canon. Much of this is focused upon the discussion of its generic development, its politically disruptive nature as a music genre, and the construction of its history, however exclusive that might be (Savage 2002; Ogg 2006; Robb 2006). Within moving images, documentaries such as The Filth and the Fury (Temple, 2000), The Clash: Westway to the World (Letts, 2000) and The Punk Rock Movie (Letts, 2008) have all contributed to the canonization of particular bands, performers and artistes within the popular conception of punk history. While the canonical narratives of punk tended to concentrate on popular punk bands such as the Sex Pistols, The Clash and The Damned, for example, we can understand these bands as having their ideological messages commodified through their affiliation with major record labels. Outside of these major labels and their punk artistes existed a DIY punk scene known as 'anarcho-punk', which was associated with an overt sense of political commitment and authenticity. At the centre of this particular scene was the band Crass, who articulated an anarchic and pacifistic DIY ethic as a touchstone for an alternative way of living, and used punk music as a vehicle for furthering the anarchopunk movement's ideologies. Investigating the ways in which Dutch film-maker Alexander Oey mediates the story of Crass in his film There Is No Authority But Yourself (Oey, 2006), this article examines how Oey's documentary seeks to evaluate and deconstruct established canonical approaches in order to illuminate a wider set of practices at work in the mediation of punk historiography. In doing so Oey’s documentary rewrites the narrative of punk history in a way that takes account of the 
significance of punk's underbelly. Within this article I will show that, although the Crass documentary may on the surface appear to be generic and non-challenging, with regard to a narrative interspersed with archive material, it considers the reconstruction of the past in its grafting of Crass onto the punk narrative timeline. It also considers how current activities of the band members continue to be influenced by their early political principles and the political directives of the anarcho-punk movement. Alexander Oey's documentary takes its title from the final lines of the Crass album Yes Sir, I Will (1983), 'You must learn to live with your own conscience, your own morality, your own decision, your own self. You alone can do it. There is no authority but yourself', and thus reflected the bands dogmatic belief in one's personal responsibilities to enable change. In his previous work Alexander Oey is renowned for documenting stories that challenge some of society's accepted values and has engendered controversy with his previous films Euro-Islam According To Tariq Ramadan (Oey, 2005), My Life as a Terrorist: The Story of Hans-Joachim Klein (Oey, 2005) and Negotiating With Al-Qaeda? (Oey, 2006).

\section{Keywords}

anarcho-punk

Crass

punk

canon

documentary

punk cinema 


\section{Introduction}

But if punk stops in 1979, then it can be argued that that there is a great deal of the story left out. This includes punk offshoots such as.... the anarcho-punk movement, with bands such as Crass who took the anarchist message seriously... (Sabin 1999: 4)

Roger Sabin's analysis of the histories of punk is very telling. It is in this context, of how histories of popular music are constructed, documented and presented, that this article examines the documentary There Is No Authority But Yourself (Oey, 2006) directed by Dutch director Alexander Oey, focusing on the anarcho-punk band Crass. ${ }^{1}$ This documentary is important in providing a detailed analysis of a band that has been mostly excluded from standard stories of popular music, and even from a more focused examination of punk as a broader popular musical genre. Discussing the documentary, therefore, allows us to engage with a neglected part of popular music history. Oey is not generally known as a director of popular music history documentaries, and his previous work has caused some controversy because the subject matter of his films usually focuses on topics seen to be outside the conventions of social acceptability, including studies of terrorism, radical Islam and Al-Qaeda.

Given this controversy about subject matter, it is interesting to note that Oey works in a quite conventional documentary style. The contrast between Oey's documentary of Crass and The Blank Generation (Kral and Poe, 1976), The Punk Rock Movie (Letts, 1978), The Great Rock ' $n$ ' Roll Swindle (Temple, 1980) or The Filth and the Fury (Temple, 2000), for example, is instructive. Kral and Poe, Letts and Temple seem interested in making their films visually articulate both the punk aesthetic and the sound of the music they document. As I will show, Oey presents the story of Crass in 
a different manner to these film-makers, as he does not attempt to visually articulate punk's sound or style.

In this article I link the issue of documentary style to questions about documentary as historiography. By this I mean how documentaries are used as a way of presenting and documenting history - specifically how we find out about and present the history of popular music for the screen. I intend to use Oey's film to go beyond the classification of televisual representations of popular music as 'rockumentaries'. ${ }^{2}$ To do this I distinguish between what I am describing here as 'standard music histories' exemplified by the BBC's Britannia ${ }^{3}$ series (2005), the avant-garde approaches taken by Letts and Temple, and the approach typified by Oey. Generally, I want to suggest that the first two approaches, for all their differences, tend to represent popular music histories through the utilization of what can be seen as the 'canon' or the processes that contribute to the formation of the canon, of which I will return to later in this article. In turn, these films and programmes function to further reinforce and make real those particular histories.

There Is No Authority But Yourself (Oey, 2006) sits outside both the popular histories of punk and the broadly recognized or widely accepted canon of punk on two levels. Oey's subjects - Crass, and the wider anarcho-punk movement - as Sabin (1999), Berger (2006) and Cross (2007) suggest tend to be overlooked in the popular histories of punk. I have in mind works of Marcus (1993a, 1993b), Savage (1991), Boot and Salewicz (1996) and Gibbs (1996), forming a basic literature survey that seems to point to a consensus of the history and development of punk. Prominence is given to bands such as the Sex Pistols, The Clash and The Damned, who are understood to have popularized and/or commodified punk through their engagement with major record labels and the dominant political economy of the music industry. In addition, as a documentary maker, rather than a 'punk film' (Thompson 2004a) maker or 
television historian, Oey ignores the processes associated with how popular music canons are constructed and more widely accepted. In doing so he offers a distinctly different way to understand punk and the place Crass has within punk and punk histories.

In what follows, then, I first discuss the notion of the popular music canon and its role in popular music histories. Within this I suggest that, in the development of a punk canon, Crass has generally been overlooked and that a recent interest in Crass has questioned the validity of that punk canon. Second, I give a brief overview of Oey's documentary There is No Authority but Yourself to contextualize this study. I explore the distinction between types of 'rockumentary', to consider the generic conventions of these forms by contrasting their style and aesthetics. Here I will also consider how music documentaries present music history through the use of particular tropes. Following this I discuss the Crass documentary in relation to Alexander Oey's other films and consider the role of the director/editor and the part they play in the processes of mediation through which this particular history is told. Finally, I discuss the need to reconsider the role of the canon in popular music histories and in doing so suggest that the film presents a different approach to the presentation of popular music history for the screen.

\section{'They said that we were trash but the name is Crass not Clash' (Crass, 1979)}

...a canon is the collection of works and artists that are generally considered to be the greatest in their field. These are the works and artists that are studied in schools, universities, performed in concert halls and displayed in galleries. These works are passed down from one generation to the next and the artists are celebrated in histories.... (Jones 2008: 5) 
The existence of a canon has historically featured more predominantly in English literature where, from the listing of great texts from the Bible and from early theologians of Christianity in the fourth-century AD (Jones 2008: 5), collections of literary works were celebrated as being the most important and influential in shaping western culture. In time the notion of the canon encompassed art and classical music but the processes of canonization tended to be elitist. This has also been the case within canons of music where the emergence, construction and reception of popular music canons has changed with the development of society and culture from so-called high-art music, where the list of composers and works has been long established, to encompass popular music. The traditional and past approaches to the formation of the musical canon have tended to focus on the musicological aspects over and above the social, cultural and political aspects of when the music was composed and consumed. This of course has not gone unchallenged and has been at the centre of an ongoing political and cultural debate about who has the authority to determine what works are worth including or omitting, This political and cultural struggle, between what is worth documenting and how they should be remembered, plays an important role in how histories are produced, maintained and consumed. I would argue then that popular music canons could be considered cultural objects that not only serve the purpose of constructing a list or body of work of 'artistic value' and celebrate the 'genius' but also act as an agent or central mechanism for the historicizing of popular music, supporting and underpinning the construction of narratological timelines of popular music's historiographies and development. As Anti-Ville Karja suggests,

..If history is about choosing those things that are worth telling, then canonisation could be described as choosing those things that are worth 
repeating......in a sense, it is possible to write the history of anybody, but in order to be canonised that anybody must be accepted more broadly. (Kärjä 2006: 5)

The formation of popular music canons has tended to rely on academics, critics, journalists and bodies of recordings (Kärjä 2006; Jones 2008). Similarly, certain artists/bands have been favoured over others by academics, journalists and critics alike when constructing popular music histories.

Popular music studies as an academic discipline ...owes as much to rock journalism as it does to various more traditional disciplines... that... the ongoing history writing of rock is discharged by journalists. and ....even when written by persons distinguished in academic community, the trend towards the more 'popular' question of how it really was is significantly stronger than towards asking was it really like that. (Kärjä 2006: 7)

This is clearly evident in the popular music press, such as Mojo magazine, $Q$ magazine and Rolling Stone, where there are regular attempts at canon formation through the inclusion of 'lists', such as the 'Greatest 50 Albums of All Time', which are reified and validated by journalists and editors in an attempt to give the bands or artists a position of authority and authenticity.

It could be argued that there is a common narrative or discourse surrounding histories of punk and what has been deemed authentic, significant and popular. A lot of attention focuses on the commodified and popularized large bodies of work in film, 
TV, literature on the Sex Pistols, The Clash, etc. Marion Leonard suggests that popular music canons

....are sometimes presented as definitive guides to a music genre or era or a detailed retrospective of a particular year or performer. Although there is a degree of variance in the artists selected for inclusion, a number of artists are regularly cited as 'important'. (2007: 27)

Within the popular narratives of punk histories very little material is seemingly written about Crass and the anarcho-punk movement that Crass unwittingly fostered (Rimbaud 1998). Crass and anarcho-punk seem to have been rendered almost invisible in a large number of these popular works and historiographies. It seems rather strange that, when the populist punk histories and the punk canon are discussed and constructed, Crass, and the anarcho-punk movement, seems to be either largely omitted from it or at best there is a fleeting reference to them.

In the flood of publications addressing different aspects of the punk phenomenon that have appeared in the last few years, it's striking how often the experience of anarcho-punk is absent. Although a few short treatments of Crass have been published, most of the key debates currently animating both the academic and the popular literature on punk simply exclude anarcho-punk from their frame of reference. This is an all the more glaring omission given the sophistication of anarcho-punk's own critique of punk practice, and the profound significance which Crass and other artists invested in the medium of punk. (Cross 2004: 26) 
Richard Cross's (2007) review of more recent literature on anarcho-punk by Ian Glasper (2006) and George Berger (2006) gives perhaps a useful insight into some of the possible reasons for the omission of Crass and anarcho-punk from popular historiographies of punk and the punk canon when he states:

The burying of the specifically anarchist strand of punk within the historiography of punk rock is not simply the outcome of a nefarious conspiracy amongst retired rock journalists - although that conspiracy does exist, as much fuelled by ignorance and arrogance as by malice. Mainstream eulogizers of punk always face great difficulty in trying to incorporate anarcho-punk's searing critique of punk orthodoxy into their own reassuringly-familiar Bromley Contingent narratives.... Anarcho-punk opted instead for an autonomous existence and a life apart - making it easier for both malevolent and for myopic historians to try to write it out of the record. (Cross 2007, online)

Moreover, Cross continues by saying that, despite interventions from authors such as Rimbaud (1998), Glasper (2006) and Berger (2006) to address the exclusion of Crass and anarcho-punk from punk narratives, publishers continue to re-produce 'the history of commercial Pistols-authored punk' (Cross 2007) and by doing so reinforce its omission from popular punk histories.

In the past decade there has been increasing interest in 1980s British anarcho-punk among academics and authors (Dines 2004; Gosling 2004; Glasper 2006; Mitchell 2006; Cross 2007, 2010; Ogg 2009; Raposo 2011; Liptrot 2012; Grimes in press) 
along with the imminent publication of The Aesthetic of Our Anger: Anarcho-Punk, Politics, Music, 1979-84 (M. Dines and M. Worley, in press), a co-edited collection of essays on British anarcho-punk and its legacy. There have also been a number of publications with a specific focus on Crass (Gordon 1996; McKay 1996; Cross 2004; Thompson 2004b; Berger 2006; Webb 2015), including works from members of Crass documenting their personal involvement in Crass and the anarcho-punk movement (Rimbaud 1998; Ignorant and Pottinger 2010). There has also been a resurgence in media interest around Crass and their apparent influential position within punk histories, with an article in the Guardian claiming that Crass's political punk is as relevant now as it was when it was written and performed (Swash 2010). Vice magazine (2010) published an interview with Penny Rimbaud and Steve Ignorant from Crass about the re-mastering of Crass's back catalogue. In the introduction to the article the author, Andy Capper, reaffirms Crass' lack of inclusion in punk histories by clearly stating:

If you pick up some crap book about the history of punk rock, chances are there will be about 90 pages dedicated to Joe Strummer's jackets but only two sentences about Crass. This is despite them selling millions of records, singlehandedly creating the DIY punk blueprint........... but not a lot of people know their actual story. ......we feel that everybody with even a passing interest in punk rock should hear it. (Capper 2010)

I would suggest that Vice magazine deems this history important enough to be worthy of inclusion in their publication as a way of informing those histories. 
In January 2011 Mojo magazine printed an article written by Jon Savage, based on unpublished interviews that he conducted with Crass in 1989, five years after they had disbanded, during the research for his book Englands' Dreaming (J. Savage, 1991).

The idea was to interview the band and use the material as the basis for a long post-script, which would have continued the story of punk on to the mid 1980's. Unfortunately it became clear that this lay beyond the scope of the book, so it remained unpublished until now. (Savage 2011: 69)

What is interesting here is not only the fact that the unpublished material has never previously found its way into the public domain but also the decision of the editors and the author to now include this particular interview 22 years later, not in a publication specifically associated with punk but one predominantly associated with music nostalgia. Mojo's fascination with and documentation of musical history is apparent from the front covers of their magazine, which lean towards a rock-centred subject matter and rock discourses present therein. From the perspective of Mojo the importance of Crass' influence on punk can only be appreciated by the band becoming or being an object of nostalgia, potentially aligning them to a non-punk canon.

\section{Locating There Is No Authority But Yourself'}

There Is No Authority But Yourself was released in 2006, extending the work of Alexander Oey, who had previously directed numerous documentaries, predominantly for Dutch TV networks VPRO and NPS. The documentary was premiered at the 'Raindance Film Festival' in October 2006 and also formed part of the official film selection programme at the 'Flipside Film Festival' in May 2008. This is Oey's first 
foray into music-based documentaries, ${ }^{4}$ and instead of focusing on more mainstream or popular artists, which would perhaps have gained greater notice or attracted larger audiences, he has created a documentary portrait of an avant-garde/anarcho-punk band who performed and produced records from 1977 to 1984 . The title of the documentary is taken from the closing lines of the band's album Yes Sir, I Will (Crass 1983). The documentary consists of interviews with three former members of Crass Penny Rimbaud, Steve Ignorant and Gee Vaucher - interspersed with archive footage. By taking Crass as his subject, a band that ceased making music and performing more than 30 years ago and is not well represented in popular music histories, it is unsurprising that this documentary remains to some degree unnoticed outside of a Crass and anarcho-punk fan community, the wider punk community, or gained any real attention by journalists or academics.

\section{'Rockumentaries' and 'Punk Cinema'}

There has been increasing interest among academics (Romney 1995; Wootton 1995; Beattie 2005; Stahl 2008; Bratus 2010) in the interrogation and analysis of the music documentary form through its production processes, generic style and narrative tropes (Edgar et al. 2013). There are, perhaps, two predominant types of popular music documentaries, sometimes referred to as 'rockumentary', that have emerged (Stahl 2008: 236-38).

1. The concert/tour movie, usually comprising an extended live performance such as Ziggy Stardust and The Spiders from Mars (Pennebaker, 1973) and Stop Making Sense (Demme, 1984), sometimes chronicling a band or artist's tour such as Gimme Shelter (Maysles et al., 1970) or music festivals such as Woodstock (Wadleigh, 1970) or more recently Glastonbury (Temple, 2006). 
2. The biographical 'rockumentary' focusing on a particular band or artist such as Foo Fighters: Back and Forth (Moll, 2011), Lemmy (Olliver and Orshorski, 2010) and Patti Smith: Dream of Life (Sebring, 2008).

Popular music documentaries have a tendency to replicate or share similar production styles and generic conventions, particularly so in the use of music documentary as a way of presenting history. More often than not we tend to see a linear narrative and chronology, with the performers viewed onstage alongside or juxtaposed with what Jonathan Romney (1995) calls 'backstage'5 . Another familiar style is the inclusion of archival material that at times is juxtaposed with contemporary material, thus locating the subject within a particular historical context. Similarly, in an attempt to represent historical fact and/or a singular truth there is often some level of commentary by either the protagonist(s) of the documentary and/or the voice of a narrator or the producer/director. This narration, as Nichols (2001) suggests, is perceived by the audience as a voice of authority and therefore gives agency to the representation of 'truth' and 'historical fact' within the documentary. ${ }^{6}$ As Corner (1996) suggests, the core tenet of documentary is its claim to truth and reality. In doing so one could argue that, through the narration, a sense of 'realism' is being presented to the viewer for interpretation. Beattie argues that non-fictional realism 'functions to render persuasive the arguments and claims made in a film or programme about the socio-historical world' (2004: 14). He further argues that the documentary form provides the viewer with an inferential relationship between them and the represented events. The viewer is offered bits of evidence and argument that they construct as truths in an expectation of being 'told' the truth. These truth claims reflect a trust bond between documentary producers and audiences that the representation being shown to them is based on the 
actual socio-historical world. The viewers therefore 'come to the documentary with a set of expectations regarding the work's authenticity and veracity' (Beattie 2004: 12).

However these types of 'rockumentaries' and their shared stylistic tropes are reflected in the depth and breadth of work within a number of texts and deserve recognition, but I want to focus on work that in some way actively historicizes. By this I mean the processes involved in the recording or narration of particular historical details or materials that subsequently makes or appears to make them historical. I would argue that these types of 'rockumentaries' are documenting a particular moment rather than actively seeking to historicize. However, as a viewer in the present we interpret them as actively or purposely historicizing because we are now looking at them as past events.

For all their differences, however, 'rockumentaries' tend to focus on artists that appear in the canon of popular music, which itself is seen as representative of a set of values that reflect important musical artists, further reinforcing their position of importance and worthiness within popular music. Tim Wall and Paul Long (2012) argue, in their chapter about Tony Palmer's series All You Need Is Love: The Story of Popular Music (Palmer, 1977), that the application of high-art canonical values in an understanding of contemporary music is problematic and ultimately not a productive model for reading popular music.

The BBC's Britannia series takes the approach where historicizing is the primary activity and in doing so starts with the canon and then constructs the narrative to satisfy that position. Wall and Long's (2010) analysis of BBC 4's Britannia series offers us some useful insights into how television engages with particular processes in the documentation and construction of histories of differing popular music genres. In their analysis they note that in the first three episodes that make up Jazz Britannia (Episodes 1, 2 and 3 2005), the producers developed a successful format that was 
reproduced across the entire series, including Punk Britannia (Episodes 1, 2 and 3 2012), wherein anarcho-punk, as a subgroup of punk rock, is given very little credence, perhaps due to the challenges that the inclusion of anarcho-punk would present, as previously highlighted by Cross $(2004,2007)$, to the director and producers in constructing their history of punk. In doing so this successful format took precedence over the subtle generic differences of each musical form. Wall and Long's (2010) critique of the over-arching narrative deployed in the Britannia series tells us as much about the desire of the producers to present 'answers' to the many paradoxes created by documenting popular music history, and in this reductive process presents us with a totalizing history (Wall and Long 2010: 23). This quest for coherence has all the characteristics of canon formation. Although the approaches of both Palmer's work and the Britannia series seek to achieve the same aim, their differences lie in that Palmer's approach allows the audience to ask questions, whereas the Britannia series seems to present those histories in what Adorno (1941) refers to as a pre-digested form, where it tells us rather than invites us to ask questions about popular music history.

\section{Punk Cinema}

In contrast to some of the more conventional 'rockumentaries' and the BBC's Britannia series, early punk rock cinema followed an approach to film and visual representation that reflected the mood and style of the emergent punk scene. Punk rock's amateurish approach to music making had its similarities in some of the visual material that documents that time. Punk cinema's alternative approach to film-making (Thompson 2004a) is exemplified by Punk Rock Movie (Letts, 1978) and The Blank Generation (Kral and Poe, 1976), both of which espouse punk's DIY ethos insomuch as the film-makers need not demonstrate any technical or formal film training in order to be creative. These low-quality personal films capture the Zeitgeist of the early punk 
scenes in both the United Kingdom and the United States in a way that reflects the energy and chaos present in punk. This visual style has continued among many punk film and video makers, where low production values reflect both the music and the subcultural ideologies within the punk scene. Other early punk films took a different, more artistic, approach to film-making. Jubilee (Jarman, 1978) had a more avantgarde cinematic approach, informed perhaps by Jarman's art school background. Julien Temple, Cambridge educated and an alumnus of the National Film School, also took a more artistic avant-garde approach to film-making in the production of his first music documentary, The Great Rock 'n' Roll Swindle (Temple 1980). Temple combined and assembled new and previously unseen footage, animation, archive and performance in a 'bricolage' approach that was reflective of the cut-and-paste style of punk fanzines circulating at that time, to create a 'story' of the rise and fall of the Sex Pistols (Mc Gillivray 2006).

Some of the early punk cinema directors, such as Temple and Don Letts, continued with this style in their later punk music documentary productions. Ailsa Grant Ferguson (2012) strongly argues against the superficial aspects of Temple's The Filth and the Fury (2000) and its association with the 'rockumentary' format. In doing so she presents a strong argument for its formal and structural deviation from the 'rockumentary' style. This is achieved through, again, a combination of bricolage techniques, which represent punk's aesthetic, and the transgression of a number of Nichols's (2001) standard modes of documentary film and Bordwell and Thompson's (2008) taxonomy of the rhetorical form. Although The Filth and The Fury (Temple 2000) appears to follow the 'rockumentary' style, Ferguson argues that its transgressive approach in fact parodies the 'rockumentary' format. Letts also employs some of those earlier stylistic punk approaches in Westway to the World (Letts, 2000). However, with Punk: Attitude (Letts, 2005) he tends to follow the more conventional form of the 'rockumentary' rather than display the 'attitude' incumbent in its title. 


\section{Contextualizing There Is No Authority But Yourself}

Oey is not recognized as a music documentary maker through his previous work, and I would suggest that by choosing difficult and challenging subjects his interest is in documenting stories that focus on people that exist on society's periphery or challenge accepted values. Perhaps some of the controversy that existed around Crass during the period that they recorded and performed is what attracted him to documenting their 'story', rather than seeing this as a conscious decision to create a music documentary.

Oey's earlier involvement with combining film and avant-garde music (see endnote 7) is not a developed or central aspect of this particular documentary film either, which could be seen as counter to the notion of Crass being considered avant-garde punk and in contrast to some of the avant-garde approaches of earlier punk documentary film-makers. What is also insightful here is that he has not produced or directed a feature length music documentary since, which suggests that the 'musical' grounding of this documentary is secondary to the telling of a particular story. Considering Oey's style in some of his previous work, I would suggest that he sets out to directly capture reality and then represent it 'truthfully'. Oey tends to allow the subjects of his documentary to have the space to tell their 'own' story; his role is seemingly one of observer rather than interviewer as there is very little verbal intervention or explicit authorship from Oey. This approach seems to follow some of Nichol's (2001) observational mode insomuch as Oey engages with his protagonists in their everyday settings and an engagement with their everyday lives. Oey engages with (some of) the members of Crass in their own homes or in familiar settings, with Penny Rimbaud and Gee Vaucher at Dial House ${ }^{7}$ and Steve Ignorant predominantly in the back garden of his home and his local pub. However, this observational mode is challenged by the 
inclusion of interviews where the protagonists are speaking directly to the camera, thus disrupting the notion of the observer not engaging with the subjects.

Through the protagonist's narratives it becomes apparent that Dial House plays a central role in the development of Crass; however, we do not see the three members together at this location engaging in a shared historical narrative. What is not revealed to the viewer is whether this separation of the protagonists was an editorial, logistical or personal outcome. Nichol's (2001) expository mode is also somewhat adhered to in the Crass documentary where most of Oey's questions, verbal interventions and narrations during the filming process have been edited out. Here Oey steps back from the narrator's role of being the authoritative voice, and he allows the protagonists to tell their 'own' story as if to highlight the importance of the members of Crass in dominating the documentaries' narratives. This step-back approach is apparent in some of Oey's previous work. Rather than there being one dominant voice, the documentary is constructed from a multiplicity of voices, which in turn divides the 'voice of authority' between those different narrators. What is interesting here is that the narratives of Steve are at times in contrast to Penny and Gee; that is not to say that the documentary is presenting a contradictory account of events, but rather it challenges the notion of a singular truth, and moreover there are differences in the ways in which experiences of their shared history are interpreted and represented as 'historical fact'. For the viewer their expectations of a singular truth are somewhat disrupted by the subversion of the expository mode. Additionally, Oey's approach implies to the viewer that the protagonists are speaking for themselves, but, through the processes of editorial mediation, we are presented with Oey's version of events, raising questions about how history is presented. Steve Ignorant's narrative seems to focus more on the history of Crass and his personal involvement with it in the sense of Crass being a 'band'; for Penny and Gee, the documentary seems to function as a platform for articulating a much broader set of beliefs such as community, pacifism, 
freedom and anarchy, as well as living an alternative lifestyle outside of the framework of mainstream society. For both of them the historical perspective on

Crass was that the band was another medium for articulating those beliefs and ideas that they are still trying to maintain in the present. For Penny and Gee their focus, and this particular (his)story, is presented in a way that positions it between past events and the continuation of them living by those core beliefs. Thus, in attempting to document the past a more interesting activity takes place where Oey becomes more fascinated with the narrative of the present, making this work unique and interesting in its presentation of history.

I want to return to the earlier issue of style and how music documentaries are presented as historiography through stylistic and generic devices. In particular I would question why Oey actively chose not to employ some of the DIY stylistic approaches and production values deployed in earlier punk cinema and punk documentaries. Stacey Thompson argues that '.....punk film-makers like punk musicians, would produce their work with little or no specialized training and without prohibitive financial investments...' and more tellingly '...their work would have to reflect these material concerns aesthetically' (2004a: 49). Don Letts' approach to documenting the nascent punk rock scene very much set out to engage with that DIY ethos. By filming on a Super 8 camera Letts actively chose to work in a way that he considered to be punk, in its approach to film-making, and in doing so created a rhetoric that communicated the punk aesthetic. ${ }^{8}$ Similarly, Temple specifically set out to create a rhetoric that would take the attitude and aesthetic of punk and by combining sound and vision communicate that attitude and aesthetic.

In contrast, Oey actively chooses not to visually articulate a sense of DIY production reflective of, and at the core of, punk. Similarly he chooses not to make the documentary in a more avant-garde style, as he did with his short video about 
Merzbow, which may have been more representative of Crass and how they sound. However, there is a noticeable analogy between Oey's short avant-garde film of Merzbow, his interviews with terrorists and radicals, and this documentary about Crass. Merzbow produces avant-garde music that is at the extremes of the frameworks of popular music, and Oey wanted to document that in a similarly avant-garde way. Likewise the lives of the terrorists and radicals that Oey documents in Euro-Islam According To Tariq Ramadan (2005), My Life as a Terrorist: The Story of HansJoachim Klein (2005) and_Negotiating With Al-Qaeda? (2006) are also, for many, at the extremes of society and beyond comprehension. In those films Oey changes his production style, in documenting their lives, by putting that controversial subject matter into a space that enables investigation and consideration by the audience. The same could be said of the Crass documentary and why he did not employ the aesthetics and DIY approach of punk cinema; he has moved from avant-garde aesthetics to other forms of mediation that seem to invite us, as an audience, to look, listen, contemplate, reflect and question the subjects he documents.

\section{Conclusion}

Punk and its relationship with the canon are both problematic and paradoxical, as the very aspects that are ascribed canonical value in popular music, such as a musical tradition, are rejected by its ethos; however, it was swiftly included in the canon of popular music. Additionally, within popular music canon punk has its own processes of canonization in place; we can witness and engage with a vast punk oeuvre that documents its history and development, but Crass, and the wider anarcho-punk subculture, seems to have mostly been rendered insignificant in these histories, although one could argue that within the construction and development of an anarchopunk canon there is little doubt that Crass would be writ large. However for Oey, Crass is an interesting subject, precisely because of their and anarcho-punk's 
problematic position at both the margins of construction of popular punk histories and their absence from them. This is perhaps due to the avant-garde nature of their music, their continual critique of punk orthodoxy and their condemnation of the willingness of other punk bands to be co-opted and commodified by the dominant corporate music and cultural industries. Paradoxically, what music historiographies generally aim to do is to take these problematic issues and moments of disruption and either ignore them or try to make sense of them by incorporating them into that particular history in a simplified way. In doing so they dilute those interesting challenges by ascribing a less complex coherent meaning to them. This quest for coherence has all the characteristics of canon formation as demonstrated in the Britannia series. Letts and Temple's work is stylistically different from the Britannia series; however, their work sets out to achieve the same aim by engaging with canonical activity or the totalizing of punk histories. Temple, and similarly the BBC Britannia series, starts from the position of an established and recognized canon, or at least a simple unifying narrative, and then constructs their work to satisfy that narrative. So what emerges is a connected process of construction in the documentary, through the selection of material, the order in which it is placed, editorial choices, the narrative it employs, and the reinforcement of the canon; both constructive processes focus around the principles of inclusion/exclusion based around a set of ascribed values and judgements.

What distinguishes Oey's documentary is that it does not neatly fit into the Britannia or avant-garde punk approach to creating popular music histories. In documenting Crass it would appear that perhaps Oey's intention is not as straightforward as presenting the story of Crass in order to situate them within the history of popular music. It could be argued that Oey purposefully chooses to not place Crass within a history of punk because he has no interest in rewriting or re-presenting that history in a way that constructs a narrative that accommodates the band. Similarly, his work 
avoids locating Crass within the canon because it is not Oey's intention to historicize them through the processes generally associated with canon formation. What Oey does achieve in his approach to documentary construction and production values is that he eschews the more traditional 'rockumentary' approaches to film-making and in doing so attempts to reflect more accurately the aesthetics and DIY ideologies of Crass.

However, its production and release in 2006 could be seen as timely in that it came at the vanguard of an increasing corpus of work that has been emerging, re-examining the significance of Crass, the anarcho-punk movement they fostered, and their position within the popularized histories of punk that they have previously been excluded from. What this documentary contributes to that corpus is an additional perspective that challenges current popular punk histories and asks us to reconsider how the popular past is constructed and presented through canonical activity and the medium of documentary.

\section{References}

Adorno, T. W. (1941), 'On popular music', Studies in Philosophy and Social Science, 9, pp. 17-48.

Barber, C. (2006), 'No future now: Derek Jarman', in C. Barber and J. Sargeant (eds), No Focus, London: Headpress.

Beattie, K. (2004), Documentary Screens: Non Fictional Film and Television, London: Palgrave Macmillan.

(2005), 'It's not only rock and roll: "Rockumentary”, direct cinema, and performative display', Australasian Journal of American Studies, 24:2, pp. 21-41. 
Berger, G. (2006), The Story of Crass, London: Omnibus Books.

Bratus, A. (2010), 'Popular music and cinema: How the rock artist is represented on the big screen', Worlds of Audio Vision, Università degli Studi di Pavia, http://www5.unipv.it/wav/pdf/WAV_Bratus_2010_eng.pdf. Accessed 15 January 2012.

Britannia (2005-, UK: British Broadcasting Corporation).

Boot, A. and Salewicz, C. (1996), Punk: The Illustrated History of a Music Revolution, London: Boxtree Ltd.

Bordwell, D. and Thompson, K. (2008), Film Art: An Introduction, New York: McGraw Hill.

Capper, A. (2010), 'Anarchy and peace, litigated', http://www.vice.com/read/anarchy-and-peace-litigated-490-v17n8. Accessed 10 December 2015.

Corner, J. (1996), The Art of Record: A Critical Introduction to Documentary, Manchester: Manchester University Press.

Crass (1979), White Punks On Hope, UK: Crass Records. (1983), Yes Sir, I Will, UK: Crass Records.

Cross, R. (2004), 'The Hippies now wear black: Crass and the Anarcho-Punk Movement, 1977-84', Socialist History, 26, pp. 25-44. (2007), “"The other history of punk”, a review of George Berger's The Story of Crass (London: Omnibus 2006)', Freedom, no. 27, 
https://thehippiesnowwearblack.wordpress.com/2007/06/03/the-other-history-of-

punk-freedom-27-april-2007/. Accessed 10 December 2015.

(2010), “"There is No Authority But Yourself”: The individual and the

collective in British Anarcho-Punk', Music \& Politics, 4:2, Summer, pp. 1-20.

Demme, J. (1984), Stop Making Sense, USA: Talking Heads; Arnold Stiefel

Company.

Dines, M. (2004), 'An investigation into the emergence of the anarcho-punk scene of the 1980's', Ph.D. thesis, Salford: University of Salford.

Dines, M. and Worley, M. (eds) (in press), The Aesthetic of Our Anger: AnarchoPunk, Politics, Music, 1979-84, Brooklyn NY: Minor Compositions/ Autonomedia (accepted for publication December 2013).

Edgar, R., Fairclough-Isaacs, K. and Halligan, B. (eds) (2013), The Music Documentary. Acid rock to Electropop, Abingdon: Routledge.

Ferguson, A. (2012), 'Every tongue brings in a several tale: The filth and the fury's counterhistorical transgressions', in R. Edgar, K. Fairclough-Isaacs and B. Halligan (eds), The Music Documentary: Acid Rock to Electropop, London:Routledge.

Gibbs, A. (1996), Destroy: The Definitive History of Punk, Virginia: Britannia Press.

Glasper, I. (2006), The Day The Country Died: A History of Anarcho-punk 19801984, London: Cherry Red Books. 
Gordon, A. (1996), Throwing The Punk Rock Baby Out With The Dirty Bath Water: Crass And Punk Rock, A Critical Appraisal, Nottingham: Do One Press.

Gosling, T. (2004), “'Not for Sale”: The underground network of anarcho-punk', in A. Bennett and R. A. Petersen (eds), Music Scenes: Local, Translocal, and Virtual, Nashville: Vanderbilt University Press.

Grimes, M. (in Press), 'From protest to resistance: British anarcho-punk fanzines (1980-1984) as sites of resistance and symbols of defiance', in M. Dines and M. Worley (eds), The Aesthetic of Our Anger: Anarcho-Punk, Politics, Music, 1979-84, Brooklyn, NY: Minor Compositions/ Autonomedia (accepted for publication December 2013).

Ignorant, S. and Pottinger, S. (2010), The Rest Is Propaganda, London: Southern Records.

Jarman, D. (1978), Jubilee, UK: Whaley-Malin Productions; Megalovision.

Jazz Britannia (Episodes 2 and 3, 2005, UK: British Braodcasting Corporation). (Episode 1, 2005, UK: British Broadcasting Corporation).

Jones, C. W. (2008), The Rock Canon: Canonical Values in the Reception of Rock Albums, Aldershot: Ashgate.

Kärjä, A.-V. (2006), 'A prescribed alternative mainstream: Popular music and canon formation', Popular Music, 25, pp. 3-19. 
Kral, I. and Poe, A. (1976), The Blank Generation, USA.

Leonard, M. (2007), Gender in the Music Industry: Rock, Discourse and Girl Power, Aldershot: Ashgate Publishing Ltd.

Letts, D. (2000), The Clash: Westway to the World, UK: 3DD Entertainment. (2008), The Punk Rock Movie [DVD], UK: Capitol.

Liptrot, M. (2012), 'Beyond the lifespan of a scab: The longevity of the DIY punk subcultural movement in Britain', Ph.D. thesis, Bolton: The University of Bolton.

Marcus, G. (1993a), Lipstick Traces: A Secret History of the Twentieth Century, London: Penguin Books. (1993b), In the Fascist Bathroom: Punk in Pop Music, 1977-92, London: Viking.

Maysles, A., Maysles, D. and Zwerin, C. (1970), Gimme Shelter, Maysles Films; Penforta.

Mc Gillivray, D. (2006), 'Twenty five years on: Julien Temple and The Great Rock 'n' Roll Swindle', in C. Barber and J. Sargeant (eds), No Focus, London: Headpress.

McKay, G. (1996), Senseless Acts of Beauty: Cultures of Resistance since the Sixties, London: Verso. 
Mitchell, G. (2006), 'Crass: Anarchism in the UK', in C. Barber and J. Sargeant (eds), No Focus, London: Headpress.

Mojo, UK: H. Bauer Publishing Ltd.

Moll, J. (2011), Foo Fighters: Back and Forth, USA: Allentown Productions; Spitfire Pictures.

Nichols, B. (1992), Representing Reality: Issues and Concepts in Documentary, Oxford: Wiley and Sons. (2001), Introduction to Documentary, Bloomington, Illinois: Bloomington University Press.

Oey, A. (2005a), Euro-Islam According To Tariq Ramadan, Netherlands: Vrijzinnig Protestantse Radio Omroep (VPRO). (2005b), My Life as a Terrorist: The Story of Hans-Joachim Klein, Netherlands/ Germany: Hessischer Rundfunk (HR); Submarine; Vrijzinnig Protestantse Radio Omroep (VPRO); Westdeutscher Rundfunk (WDR). (2005c), Negotiating With Al-Qaeda?, Netherlands: Vrijzinnig Protestantse Radio Omroep (VPRO). (2006), There Is No Authority But Yourself, Netherlands: Submarinechannel;

Vrijzinnig Protestantse Radio Omroep (VPRO). 
Ogg, A. (2006), No More Heroes: A Complete History of UK Punk from 1976 to 1980, London: Cherry Red Books. (2009), Independence Days, London: Cherry Red Books.

Olliver, G. and Orshoski, W. (2010), Lemmy, USA: Damage Case Films \& Distribution; Secret Weapon Films; Stay Free Films; Three Count Films.

Palmer, T. (1977), All You Need Is Love: The Story of Popular Music, UK: London Weekend Television (LWT); Theatre Projects Film Productions Ltd.

Pennebaker, D. A. (1973), Ziggy Stardust and The Spiders from Mars, UK: Mainman; Bewlay Bros.; Miramax.

Punk Brittania (Episode 1, 2012, UK: British Braodcasting Corporation). (Episode 2, 2012, UK: British Braodcasting Corporation). (Episode 3, 2012, UK: British Broadcasting Corporation).

$Q$, UK: H. Bauer Publishing Ltd. 
Raposo, A. (2011), Never Trust a Hippie: The Representation of 'Extreme' Politics in Punk Music Graphics and the Influences of Protest and Propaganda Traditions, London: University of the Arts London.

Rimbaud, P. (1998), Shibboleth: My Revolting Life, Edinburgh: AK Press.

Robb, J. (2006), Punk Rock: An Oral History, London: London: Ebury Press.

Rolling Stone, USA: Wenner Media LLC.

Romney, J. (1995), 'Access all Areas: The real space of rock documentary', in J. Romney and A. Wootton (eds), Celluloid Jukebox: Popular Music and the Movies since the 50's, London: British Film Institute.

Sabin, R. (ed.) (1999), Punk Rock: So What? The Cultural Legacy of Punk, London: Routledge.

Savage, J. (1991), Englands' Dreaming: Sex Pistols and Punk Rock, London: Faber and Faber.

(2002), England's Dreaming, Revised Edition: Anarchy, Sex Pistols, Punk Rock, and Beyond, London: St Martins Griffin. (2011), 'By any means necessary', Mojo, January, pp. 67-74.

Sebring, S. (2008), Patti Smith: Dream of Life, USA: Clean Socks; Thirteen / WNET. 
Stahl, M. (2008), 'Sex and drugs and bait and switch: Rockumentary and the new model worker', in D. Hesmondhalgh and J. Toynbee (eds), The Media and Social Theory, Abingdon: Routledge.

Swash, R. (2010), 'Crass's political punk is as relevant now as ever', http://www.guardian.co.uk/music/2010/oct/24/crass-penny-rimbaud-steve-ignorant. Accessed 10 December 2015.

Temple, J. (1980), The Great Rock 'n' Roll Swindle, UK: Boyd's Company (as Boyd's Co.); Kendon Films Ltd; Matrixbest; Virgin Films. (2000), The Filth and the Fury, UK: FilmFour; Jersey Shore; Nitrate Film; Panacea Entertainment; The Sex Pistols Residuals. (2006), Glastonbury, UK: Newhouse Nitrate.

Thompson, S. (2004a), 'Punk cinema', Cinema Journal, 43:2, pp. 47-66. (2004b), 'Crass commodities', Popular Music and Society, 27:3, pp. 307-22.

Wadleigh, M. (1970), Woodstock, USA: Wadleigh-Maurice Ltd.

Wall, T. and Long, P. (2010), 'Constructing the histories of popular music: The Britannia series', in I. Inglis (ed.), Popular Music and Television in Britain, London: Ashgate. (2012), 'Tony Palmer's “All You Need Is Love”, in R. Edgar, K. FaircloughIsaacs and B. Halligan (eds), The Music Documentary: Acid Rock to Electropop, London: Routledge. 
Webb, P. (2015), 'Crass, subculture and class: The milieu culture of DIY punk', in

The Subcultures Network (eds), Fight Back. Punk, Politics and Resistance,

Manchester: Manchester University Press, pp. 99-116.

Wootton, A. (1995), 'The do's and don'ts of rock documentary', in J. Romney and A.

Wootton (eds), Celluloid Jukebox: Popular Music and the Movies since the 50's,

London: British Film Institute, pp. 94-105.

\section{Contributor details}

Matt Grimes is a senior lecturer in Music Industries and Radio at Birmingham City University. He is a co-founder of the Punk Scholars Network and a member of the Birmingham Centre for Media and Cultural Research where he is currently undertaking his doctoral research into 1980s British anarcho-punk and its impact on the subsequent lives of its participants. Other research interests and publications include British anarcho-punk zines, radio and marginalized communities and the use of radio as a tool for change.

\section{Contact:}

E-mail: matt.grimes@bcu.ac.uk

Notes

${ }^{1}$ Crass was an avant-garde English punk rock band formed in 1977 from a collective of musicians based around Dial House, an open-house community in Essex. The band was formed as a direct response to what they saw as the failings of the then popular punk movement to live up to the do it yourself (DIY) and anarchist ethos often 
espoused by artists such as the Sex Pistols, The Clash, etc. Crass was seminal in the development of anarcho-punk, a specific subcultural strand of punk rock that promoted anarchism and pacifism as a political ideology and a way of living. Members of the band continue to perform under various collaborations and individual performances.

${ }^{2}$ A term first used by Bill Drake and Gene Chenault producers of the The History of Rock \& Roll (1969)-syndicated radio documentary 93 KHJ Los Angeles.

${ }^{3}$ The Britannia label consists of a series of documentaries and one-off programmes produced by the British Broadcasting Corporation about the history of popular music and their related cultural activities in the United Kingdom.

${ }^{4} \mathrm{He}$ had previously produced two short (10 min.) experimental films on Merzbow, the recording name of Japanese avant-garde noise musician Masami Akita as part of a collaborative project, Sonic Images (1998) and Sonic Fragments (2000) based on the relation between an electronic composer and a digital film-maker under the direction of Dutch documentary producer Frank Scheffer who is internationally recognized as a master of sound and image. http://www.sonambiente.net/en/01_spektrum/film.html and http://www.shadowfestival.nl/makers/biography/frank_scheffer/, both accessed 18 January 2012.

5 This could constitute a dressing room, tour bus, hotel room.....

${ }^{6}$ Bill Nichols (2001) argues for six standard modes of documentary film-making. One of these is the expository mode wherein a key feature is the authoritative voice. One of the purposes of the authoritative voice within the expository mode is to bring together parts of the historical world into a rhetorical or argumentative framework that directly addresses the viewer with voices that advance an argument, present a perspective or position or recount history. 
${ }^{7}$ Dial House is a house in Essex that was occupied by Penny Rimbaud, and others, in the late 1960s. It became a focal point for musicians, artists and performers, and it was where all the members of Crass met, formed the band and lived together. Penny continues living there today following the same ethos behind its original inception. For a full explanation of the significance and importance of Dial House in the histories of Crass see Penny Rimbaud's Shibboleth: My Revolting Life (1998); Steve Ignorant and Steve Pottinger's The Rest Is Propaganda (2010) and George Berger's The Story of Crass (2008);

${ }^{8}$ http://www.eccentricsleevenotes.com/Don-Letts\%281553948\%29.htm, accessed 19 December 2011; http://www.punk77.co.uk/groups/donlettsinterview3.htm, accessed 19 December 2011; http://www.staythirstymedia.com/201012-052/html/201012-donletts-int.html, accessed 19 December 2011. 